\title{
Baryonic Beta Dynamics: An Econophysical Model of Systematic Risk
}

\section{JAMES MiNG CHEN}

Justin Smith Morrill Chair in Law, Michigan State University, College of Law, 648 North Shaw Lane, East Lansing, 48824-1300 Michigan, USA. E.-mail: chenjame@law.msu.edu

\begin{abstract}
This essay seeks to rehabilitate the capital asset pricing model by splitting beta, the basic unit of systematic risk, into subatomic (or "baryonic") components. By analogy to quantum chromodynamics and other aspects of the Standard Model of particle physics, this essay bifurcates beta on either side of mean returns and into distinct components reflecting relative volatility and correlation, as well as cash-flow and discount-rate effects. Splitting the atom of systematic risk answers some of the most troubling anomalies and puzzles in finance, including abnormal returns on small-cap and value stocks, the low-volatility anomaly, and the equity premium puzzle.
\end{abstract}

Keywords: CAPM, Small Caps, Value, Beta, Physics, Standard Model, Low-Volatility Anomaly, Equity Risk Premium

\section{Dinámica de la Beta Bariónica: Un modelo Econofísico de Riesgo Sistemático}

\section{RESUMEN}

Este artículo pretende la rehabilitación del modelo de valoración de activos financieros mediante la escisión de la beta, la unidad básica de riesgo sistemático, en componentes subatómicos (o "bariónicos”). Por analogía con la cromodinámica cuántica y otros aspectos del modelo estándar de la física de partículas, se bifurca la beta a ambos lados de los rendimientos medios y en distintos componentes que reflejan la volatilidad relativa y la correlación, así como en los efectos flujo de caja y tasa de descuento. La escisión del átomo del riesgo sistemático da respuesta a alguna de las más controvertidas anomalías (y puzles) in finanzas, tales como los rendimientos anómalos de las acciones de baja capitalización y de valor, la anomalía relativa a la baja volatilidad y el puzle de la prima de riesgo de las acciones.

Palabras clave: CAPM, acciones de pequeña capitalización, valor, beta, física, modelo standard, anomalía de baja volatilidad, prima de riesgo de las acciones.

JEL Classification: A12, B26, G12

Artículo recibido en octubre de 2017 y aceptado en diciembre de 2017

Artículo disponible en versión electrónica en la página www.revista-eea.net, ref. ə-36111 


\section{INTRODUCTION}

This essay summarizes the central argument of my recent book, Econophysics and Capital Asset Pricing: Splitting the Atom of Systematic Risk (Chen, 2017). A generation of financial scholars has assaulted the conventional capital asset pricing model (CAPM) and beta as its basic unit of systematic risk. Econophysics and Capital Asset Pricing seeks to rehabilitate the CAPM splitting beta into subatomic (or "baryonic") components.

By analogy to quantum chromodynamics and other aspects of the Standard Model of particle physics, I bifurcate beta on either side of mean returns and into distinct components reflecting relative volatility and correlation, as well as cashflow and discount-rate effects. Splitting the atom of systematic risk answers some of the most troubling anomalies and puzzles in finance, including abnormal returns on small-cap and value stocks, the low-volatility anomaly, and the equity premium puzzle.

\section{THE STRUCTURE OF AN ECONOPHYSICAL REVOLUTION}

In finance as in other disciplines, "[n]ormal science does not aim at novelties of fact or theory and, when successful, finds none" (Kuhn, 1970, p. 52). When they arise, "fundamental novelties of fact and theory" spur progress through "the recognition that nature has somehow violated the paradigm-induced expectations that govern normal science” (ibid., pp. 52-53).

Intellectual coherence assumes supreme importance in finance, a field devoted to elaborating "uncertainty" in "theory and [in] empirical implementation" (Campbell, Lo and MacKinlay, 1997, p. 3). Finance in general and asset pricing in particular represent fantastic instances of scientific progress because the "random shocks" that propel knowledge happen to be "the subject matter" of these branches of economics (Campbell, 2000, p. 1515).

The history of mathematical finance falls into two phases (Merton, 1987, pp. 483-484). The first phase consisted of constructing an elegant, symmetrical set of rational models based on efficient markets and asset pricing according to conventional beta as its unitary, basic measure of systematic risk. From 1979 through 1999, financial scholars sought primarily to apply "the Arrow-Debreu model of general equilibrium to financial markets” (Campbell, 2000, p. 1516).

By contrast, the second phase of mathematical finance has consisted largely of deconstructing the conventional model's economic mechanisms and behavioral assumptions. Multi-factor models exposed technical flaws in the specification of risk-return relationships. Financial anomalies and puzzles revealed inefficiencies in markets that had been presumed perfect in their transmission and assimilation of new information. Investor psychology deviated from classical presuppositions of rationality. 
Econophysics applies "the techniques of statistical physics and nonlinear dynamics" to complex economic problems (Sinha, Chatterjee, Chakraborti and Chakrabarti, 2011, p. 1). Without attempting "the complete statistical characterization of the stochastic process of price changes of a financial asset" (Mantegna and Stanley, 2000, pp. 6-7), this essay harnesses econophysics as the basis of "a theoretical model that is able to encompass all the essential features of real financial markets” (ibid., p. 7; see also Roehner, 2005).

Econophysics bluntly proclaims that economics needs a scientific revolution (Bouchaud, 2008). But "science seldom proceeds in [a] straightforward logical manner" (Watson, 2001, p. xi). As tentative as they are tumultuous, scientific "steps forward (and sometimes backward)" proceed as "an adventure characterized both by youthful arrogance and by the belief that the truth, once found, would be simple as well as pretty" (ibid.). The econophysical revolution in finance thus follows a dialectic familiar throughout science: thesis, antithesis, synthesis (Fichte, 1993a; Fichte, 1993b).

\section{THE CONVENTIONAL CAPITAL ASSET PRICING MODEL}

The capital asset pricing model quantifies the risk-based premium for any asset relative to a risk-free benchmark:

$$
r_{a}=r_{f}+\beta_{a}\left(r_{m}-r_{f}\right)
$$

where $r_{a}, r_{m}$, and $r_{f}$ respectively represent returns on the asset, the broader market, and a risk-free investment, and $\beta_{a}$ represents the asset's beta vis-à-vis the market portfolio (Korajczyk, 1999, p. xv). This formula boasts convenience and "seductive simplicity" (Fama and French, 2004, p. 44).

The capital asset pricing model remains the dominant paradigm in financial risk management (Levy, 2012, pp. 4-5). "[M]arket professionals (and academics) still think about risk in terms of market $\beta$ " (Fama, 1991, p. 1593; see also Pettengil et al., 1995). The CAPM thrives despite its distinct lack of academic support. "It takes a better theory to kill an existing theory," and the financial profession has "yet to see [a] better theory" (Koller et al., 2010, p. 261).

Reminiscent "of cartoon characters like Wile E. Coyote who have the ability to come back to original shape after being blown to pieces," the CAPM endures "because (a) the empirical support for other asset-pricing models is no better, (b) the theory behind the CAPM has an intuitive appeal that other models lack, and (c) the economic importance of the empirical evidence against the CAPM ... is ambiguous" (Jagannathan and Wang, 1996, p. 4). "While there are other models to determine equity, CAPM is probably the most widely used" (Pantaleo and Ridings, 1996, p. 433 n.52). In professional practice if not academic theory, the capital asset pricing model is alive and well (Levy, 2009). 
Many predictive flaws in finance stem from the mathematically elegant but practically unrealistic construction of "beautifully Platonic models on a Gaussian base” (Taleb, 2007, p. 279). From the capital asset pricing model to the BlackScholes model of option pricing (Black and Scholes, 1973; Merton, 1973), Robert Merton's distance-to-default model of credit risk (Merton, 1974), the RiskMetrics specification of value-at-risk (Mina and Xiao, 2001; Berkowitz and O’Brien, 2002), and the Gaussian copula (Jaworski et al., 2010; Liu, 2000; Nelsen, 1999), much of the edifice of finance rests upon the normal distribution (Mandelbrot and Hudson, 2004).

In reality, returns are skewed (Aparicio and Estrada, 2001; Bekaert et al., 1998; Chunhachinda et al., 1997; Peiró, 1999) and exhibit heavier than normal tails (Gray and French, 1990; Kon, 1984; Markowitz and Usmen, 1996; Mills, 1995). Many risks follow decidedly non-Gaussian distributions (Campbell, Lo and MacKinlay, 1997, pp. 17, 81, 172, 498). Large swings of $3 \sigma$ to $6 \sigma$ occur so often that "[e]xtreme price swings are the norm in financial markets -not aberrations" (Mandelbrot and Hudson, 2004, p. 18). Empirical departures from predicted relationships between returns and volatility take "a shot straight at the heart” of asset pricing theories (Fama and French, 1992, p. 438).

Beta nevertheless "remains the most explanatory element of the risk premium in most asset pricing models" (Bellelah, Bellelah, Ameur and Hafsia, 2017, p. 864). Attacks on "standard deviation and its variations" as risk measures have failed to dislodge beta (Kaplanski, 2004, p. 637). Beta endures if only because "relatively little effort has been made" to devise "a better risk measure" (ibid.). Even models purporting to dismiss beta as "insignificant" continue to treat beta as "an important explanatory variable," despite deprecating its traditional status as "the main explanatory variable" (Levy, 2012, p. 4). "[I]n all... models, the market risk of a security will affect its equilibrium expected return, and indeed, for most common stocks, market risk will be the dominant factor" (Merton, 1980, p. 324).

For a statistic that many academics denigrate as "economically meaningless," beta is still "intensively employed" by financial professionals (Levy, 2012, p. 5). The "concept of beta risk" remains "the single most important contribution of academic researchers to the financial community" (Chan and Lakonishok, 1993, p. 51). "The CAPM is widely viewed as one of the two or three major contributions of academic research to financial managers during the postwar era" (Jagannathan and Wang, 1996, p. 4).

Throughout the 1970s and 1980s, financial scholarship identified significant departures from beta-driven asset pricing models. Small firms (Banz, 1981; Reinganum, 1981) and firms with a high book-to-market ratio (Basu, 1977; Reinganum, 1981) offered returns exceeding those predicted by beta. Fama and French (1992) declared that "the relation between $\beta$ and average return... is weak, perhaps nonexistent” (p. 464). The resulting Fama-French three-factor model of 
asset pricing according to market risk, size, and value quickly established a new, dominant paradigm (Daniel and Titman, 1997; Fama and French, 1995; Griffin, 2002).

A related body of scholarship associated with Carhart (1997) identified momentum in short-run stock prices (Grinblatt, Titman and Wermers, 1995; Jegadeesh and Titman, 1993). Because it cannot be explained by beta or by Fama and French's size and value factors (Chan et al., 1996), momentum represents a distinct factor within the comprehensive Fama-French-Carhart four-factor model (Avramov and Chordia, 2006; Fama and French, 1996; Fama and French, 2008; Fama and French, 2012; Liew and Vassalou, 2000; Rath and Durand, 2015). Size, value, and momentum are the marquee attractions in the "zoo of... factors" that defines contemporary finance (Cochrane, 2011, p. 1047).

\section{THE SUBATOMIC MENAGERIE: FROM THE "FACTOR ZOO” TO THE "PARTICLE ZOO”}

The rehabilitation of beta begins with the harmonization of the "factor zoo" of mathematical finance with the "particle zoo" of contemporary physics. The "particle zoo" is the playful name originally assigned to the particles now classified within the Standard Model (Schwartz, 1997). The intrinsic discipline governing subatomic particles in physics may help us impose clarifying order on a financial literature that often seems to emphasize size, value, and momentum, perhaps at the expanse of closer examination of the structure and dynamics of capital markets.

"In physics and in other natural sciences, it is often a successful strategy to analyze the behavior of a system by studying the smallest components of that system" (Preis and Stanley, 2010, p. 432). If examined "on steadily decreasing time and length scales," that system may exhibit complex properties and behaviors that cannot be explained by its smallest components, but rather by their interactions (ibid.). "At each stage" of any scientific progression, increasing complexity demands "new laws, concepts, and generalizations" (Anderson, 1972, p. 393).

The Standard Model of particle physics provides a fruitful analogy for the subcomponents of financial risk (Mann, 2010; Oerter, 2006). Quantum chromodynamics focuses on a subset of fermions, six quarks in three matched pairs of quark families (Weiner, 2010): 
Table 1

Generations of quarks and leptons in the Standard Model of particle physics

\begin{tabular}{|c|c|c|c|}
\hline Quarks & First generation & $\begin{array}{c}\text { Second } \\
\text { generation }\end{array}$ & Third generation \\
\hline Up-type quarks with $\mathrm{a}+\frac{2}{3}$ e charge & Up & Charm & Top (truth) \\
\hline Down-type quarks with a $-\frac{1}{3}$ e charge & Down & Strange & Bottom (beauty) \\
\hline Leptons & Electron & Muon & Tau \\
\cline { 2 - 4 } & Electron neutrino & muon neutrino & tau neutrino \\
\hline
\end{tabular}

Source: Own elaboration.

Baryons are subatomic particles consisting of three quarks. The most familiar baryons are protons and neutrons, which together account for most of the mass of the universe (Munowitz, 2005, p. 35). These two baryons are comprised of different combinations of up and down quarks:

$\begin{array}{cl}\text { proton } & 2 u+1 d=+1 e \\ \text { neutron } & 1 u+2 d=0 e\end{array}$

Since the up quark has a charge of $+\frac{2}{3}$ and the down quark has a charge of $-\frac{1}{3}$, these combinations account for proton's +1 and the neutron's neutral charge (Gell-Mann, 1994, p. 181).

"Flavors" of beta do not necessarily correspond, mathematically or otherwise, to the six flavors of quarks. It suffices to observe that the energy levels characterizing different aspects of physics can be analogized to the diverse scales at which economics operates, from households to firms and capital markets and ultimately to money supply and foreign exchange.

By the same token, certain aspects of the Standard Model, especially quantum chromodynamics, invite fruitful analogies. In particle physics, color confinement under ordinary, low-energy conditions confines quarks within hadrons such as baryons and mesons and prevents quarks from being directly observed in isolation (Wilson, 1974). Quarks of each flavor exhibit “color” - arbitrarily defined as red, blue, and green, according to the constituents of visible light.

Color $\mathrm{SU}(3)$ is the gauge symmetry that governs color change and interaction among quarks under quantum chromodynamics (Brower, Mathur and Tan, 2000; Icke, 1995; Polchinski and Strassler, 2002). Absent violations of Color SU(3) -Aaij et al. (2015), for instance, found evidence of pentaquark states with a confidence of $15 \sigma$, in contrast with the failure of Amsler et al. (2008: pp. 10191022) to detect particles consisting of five quarks -baryons consist of exactly three quarks satisfying the chromodynamic requirement of one red, one blue, and one green quark. In an econophysical representation of finance analogous to the Standard Model, the three subcomponents of beta should not only correspond to 
the three generations of quarks, but also combine in a fashion similar to quantum chromodynamics to form the full measure of conventional beta.

Inspired by the Standard Model's classification of quarks (and leptons) within three generations of matter and by quantum chromodynamics' description of three-way interaction among red, blue, and green colors of quarks, Econophysics and Capital Asset Pricing divided beta as the fundamental unit of systematic risk into three distinct groups, or "generations":

1. Up and down on either side of mean returns (Ang et al., 2006, pp. 11991200; Estrada, 2002, p. 368; Estrada, 2007, pp. 171, 174; Tsai et al., 2014, p. 441)

2. Relative volatility $(\sigma)$ and correlation $(\rho)$ between asset-specific and market-wide returns (Leibowitz et al., 2010, p. 14; Miller, 2014, pp. 198, 213, 292; Pratt and Grabowski, 2010, pp. 205-206, 214)

3. "Bad" cash-flow beta versus "good" discount-rate beta (Campbell and Vuolteenaho, 2004)

These generations of "baryonic" beta correspond to the Standard Model's generations of quarks (Harari and Stanford Linear Accelerator Center, 1997):

Table 2

Three generations of quarks alongside three generations of "baryonic" beta

\begin{tabular}{|c|c|c|c|}
\hline Generation & Quark & Beta & Mathematical relationship to conventional beta \\
\hline \multirow{4}{*}{ First } & Up & Upside & \multirow{2}{*}{$\beta_{+}=\frac{\operatorname{cov}_{+}(a, m)}{\operatorname{cov}_{+}(m, m)} ; \beta_{-}=\frac{\operatorname{cov}_{-}(a, m)}{\operatorname{cov}_{-}(m, m)}$} \\
\hline & \multirow{3}{*}{ Down } & \multirow{3}{*}{ Downside } & \\
\hline & & & $\operatorname{cov}_{+}(a, m)+\operatorname{cov}_{-}(a, m)$ \\
\hline & & & $\rho=\overline{\operatorname{cov}_{+}(m, m)+\operatorname{cov}_{-}(m, m)}=\overline{\operatorname{cov}(m, m)}$ \\
\hline \multirow{2}{*}{ Second } & Charm & $\begin{array}{l}\text { Correlation } \\
\text { tightening }\end{array}$ & \multirow{2}{*}{$\beta=\frac{\sigma_{a}}{\sigma_{m}} \rho(a, m)=\frac{\sigma_{a}}{\sigma_{m}} \cdot \frac{\operatorname{cov}(a, m)}{\sigma_{a} \sigma_{m}}$} \\
\hline & Strange & $\begin{array}{l}\text { Relative } \\
\text { volatility }\end{array}$ & \\
\hline \multirow{2}{*}{ Third } & Top (truth) & $\begin{array}{l}\text { Discount- } \\
\text { rate (good) }\end{array}$ & \multirow{2}{*}{$\beta=\beta_{C F}+\beta_{D R}$} \\
\hline & $\begin{array}{c}\text { Bottom } \\
\text { (beauty) }\end{array}$ & $\begin{array}{l}\text { Cash-flow } \\
\text { (bad) }\end{array}$ & \\
\hline
\end{tabular}

Source: Own elaboration.

The Standard Model isolates six distinct "flavors" of up- and down-type quarks within three generations of matter. It describes the interaction of quarks according to the three-way Color $\mathrm{SU}(3)$ gauge symmetry of quantum chromodynamics. Likewise, by describing three distinct ways to bifurcate beta -upside and downside beta on either side of mean returns, the relative volatility and correlation tightening components of beta, and the intertemporally dynamic distinction between "bad" 
cash-flow beta and "good" discount-rate beta - "baryonic beta dynamics" facilitates more nuanced, comprehensive evaluation of systematic risk in portfolio theory and asset pricing. Indeed, the representation of $\mathrm{SU}(3)$ as a Lie group (Curtright and Zachos, 2015; Rosen, 1971) raises the tantalizing prospect that discrete components of financial risk might be resolved by Lie algebra (Erdman and Wilson, 2006; Hall, 2015; Helgason 1978).

\section{BARYONIC BETA DYNAMICS AND BEYOND}

"These are only hints and guesses, / Hints followed by guesses; and the rest / Is... discipline, thought and action” (Eliot, 1971, p. 44). Baryonic beta dynamics imposes order on the factor zoo of contemporary finance. According to this econophysical model, systematic risk consists of coherent "subatomic" components that interact in quantifiable and perhaps even predictable ways. Far from "displac[ing] economics," physics supplies principles and analogies that "help economists find deeper understandings" of finance and related fields as “complex systems” (Richmond et al., 2013, p. 17).

If only through "qualitative analogy," physical models "have also helped to develop new theories to explain [existing] observations in Economics" (Chakraborti et al., 2011, p. 992). More generally, risk measures with clear physical interpretations provide readily understandable, easily quantifiable, and statistically verifiable support or contradiction for intuitions about risk management and portfolio design.

Baryonic beta dynamics provides persuasive, perhaps even compelling, explanations for several of the most significant anomalies in mathematical finance. Splitting beta into its constituent parts helps explain abnormal returns on small-cap and value stocks (Morelli, 2007, p. 263; Xu and Pettit, 2014, p. 69; Zhang, 2005, p. 67), the low-volatility anomaly (Leibowitz et al., 2010, pp. 235, 265; Ang et al., 2006, p. 1228; Baker et al., 2011, p. 43), and the equity premium puzzle (Campbell and Cochrane, 1999, pp. 240, 248; Mehra, 2003, p. 61; Mehra and Prescott, 2003, p. 917).

In addition, splitting the atom of systematic risk offers insight into short-term price continuation anomalies such as momentum and post-earnings announcement drift (Bernard, 1993; Bernard and Thomas, 1989; Bernard and Thomas, 1990; Savor and Wilson, 2016). Careful parsing of cash-flow and discount-rate effects opens the door to understanding capital market interactions with the macroeconomy (Campbell and Vuolteenaho, 2004; Flannery and Protopapadakis, 2002; McQueen and Roley, 1993). The econophysics of baryonic beta also invites more explicitly behavioral accounts of abnormal markets and irrational investors, such as prospect theory (Kahneman and Tversky, 1979; Tversky and Kahneman, 1992), SP/A theory (Lopes, 1987), and behavioral portfolio theory (Shefrin and Statman, 2000). 
These departures from informational efficiency and rational pricing arise from interactions among beta's baryonic subcomponents. Systematic risk behaves differently on the downside of expected return relative to the upside (Chen, 2017, pp. 31-45). Downside risk reveals the greater sensitivity of smaller, more agentspecific asset classes, such as small-cap stocks, to comovement with capital markets or the real economy. "[J]ust about every known stock market pattern is stronger for small firms than for large firms" (Loughran and Ritter, 2000, p. 363). "[H]igher average returns" from "considerably higher cash-flow betas" relative to macroeconomic discount-rate effects (Campbell and Vuolteenaho, 2004, p. 1261) explain the superlative performance of value and small-cap stocks within the three-factor model of Fama and French $(1995,1996)$.

Ultimately, the derivation of the baryonic model of finance from the Standard Model of particle physics expands the epistemic toolkit available to economics. "Nel mezzo del cammin di nostra vita / mi ritrovai per una selva oscura": Confounded by abnormal markets and irrational investor behavior, contemporary finance sometimes finds itself "[i]n dark woods, the right road lost" in "woods... so tangled and rough" (Pinksy, 1994, pp. 2-3, canto $i$, lines 1-2). "E quindi uscimmo riveder le stelle": The confluence of physics and economics marks the place "[w] here we came forth, and once more saw the stars" (ibid., pp. 372-373, canto xxxivi, line 140).

\section{BIBLIOGRAPHY REFERENCES}

AAIJ, R. et al. (LHCb COLLABORATION) (2015). "Observation of J/up Resonances Consistent with Pentaquark States in $\Lambda_{b}^{0} \rightarrow J / \psi K$ K Decays". Physics Review Letters, 115: 072001

AGUILAR-BENITEZ, M. et al. (PARTICLE DATA GROUP) (1986). "Review of Particle Physics". Physics Letters B, 170, pp. 2-344.

AMSLER, C. et al. (PARTICLE DATA GROUP) (2008). "Review of Particle Physics". Physics Letters B, 667, pp. 1-1340.

ANDERSON, P.W. (1972). "More Is Different". Science, 177, pp. 393-396.

ANG, A.; CHEN, J. and XING, Y. (2006). "Downside Risk". Review of Financial Studies, 19, pp. 1191-1239.

APARACIO. F.M. and ESTRADA, J. (2001). "Empirical Distributions of Stock Returns: European Securities Markets, 1990-95". European Journal of Finance, 7, pp. 1-21.

AVRAMOV, D. and CHORDIA, T. (2006). "Pricing Stock Returns". Journal of Financial Economics, 82, pp. 387-415.

BAKER, M.; BRADLEY, B. and WURGLER, J. (2011). "Benchmarks as Limits to Arbitrage: Understanding the Low-Volatility Anomaly". Financial Analysts Journal, 67(1), pp. 40-54. 
BANZ, R.W. (1981). "The Relationship Between Return and Market Valuation of Common Stocks". Journal of Financial Economics, 9, pp. 3-18.

BASU, S. (1977). "Investment Performance of Common Stocks in Relation to Their PriceEarning Ratios: A Test of the Efficient Market Hypothesis". Journal of Finance, 32, pp. 663-682.

BEKAERT, G.; ERB, C.; HARVEY, C.R. and VISKANTA, T. (1988). "Distributional Characteristics of Emerging Market Returns and Asset Allocation". Journal of Portfolio Management, 24(2), pp. 102-116.

BELLELAH, M.A.; BELLELAH, M.O., AMEUR, H.B. and HAFSIA, R.B. (2017). "Does the Equity Premium Puzzle Persist During Financial Crisis? The Case of the French Equity Market". Research in International Business and Finance, 39B, pp. 851-866.

BERKOWITZ, J. and O'BRIEN, J. (2002). "How Accurate Are Value-at-Risk Models at Commercial Banks?". Journal of Finance, 57, pp. 1093-1111.

BERNARD, V.L. (1993). "Stock Price Reactions to Earnings Announcements: A Summary of Recent Anomalous Evidence and Possible Explanations". In R.H. Thaler (ed.): Advances in Behavioral Finance (pp. 303-340). New York: Russell Sage Foundation.

BERNARD, V.L. and THOMAS, J.K. (1989). "Post-Earnings Announcement Drift: Delayed Price Response or Risk Premium?" Journal of Accounting Research, 27, pp. 1-36.

BERNARD, V.L. and THOMAS, J.K. (1990). "Evidence That Stock Prices Do Not Fully Reflect the Implications of Current Earnings for Future Earnings". Journal of Accounting and Economics, 13, pp. 305-340.

BLACK, F. and SCHOLES, M.S. (1973). "The Pricing of Options and Corporate Liabilities". Journal of Political Economy, 81, pp. 637-654.

BOUCHAUD, J-P. (2008). "Economics Needs a Scientific Revolution". Nature, 455, pp. 1181.

BROWER, R.C.; MATHUR, S.D. and TAN, C-I. (2000). "Glueball Spectrum For QCD From AdS SuperGRAVITY DUALITY". Nuclear Physics B, 587, pp. 249-276.

CAMPBELL, J.Y. (2000). "Asset Pricing at the Millennium". Journal of Finance, 55, pp. 1515-1567.

CAMPBELL, J.Y. and COCHRANE, J.H. (1999). "By Force of Habit: A Consumption Based Explanation of Aggregate Stock Market Behavior". Journal of Political Economy, 107, pp. 205-251.

CAMPBELL, J.Y.; LO, A.W. and MacKINLAY, A.C. (1997). The Econometrics of Financial Markets. Princeton, N.J.: Princeton University Press.

CAMPBELL, J.Y. and VUOLTEENAHO, T. (2004). "Bad Beta, Good Beta". American Economic Review, 94, pp. 1249-1275.

CARHART, M.M. (1997). "On Persistence in Mutual Fund Performance". Journal of Finance, 52, pp. 57-82.

CHAKRABORTI, A.; TOKE, I.M.; PATRIARCA, M. and ABERGEL, F. (2011). "Econophysics Review: I. Empirical Facts". Quantitative Finance, 11, pp. 991-1012.

CHAN, L.K.C.; JEGADEESH, N. and LAKONISHOK, J. (1996). "Momentum Strategies". Journal of Finance, 51, pp. 1681-1713.

CHAN, L.K.C. and LAKONISHOK, J. (1993). "Are Reports of Beta's Death Premature?". Journal of Portfolio Management, 19(4), pp. 51-62.

CHEN, J.M. (2017). Econophysics and Capital Asset Pricing: Spitting the Atom of Systematic Risk. Cham, Switzerland: Palgrave Macmillan. 
CHUNHACHINDA, P.; DANDEPANI, K.; HAMID, S. and PRAKASH, A.J. (1997). "Portfolio Selection and Skewness: Evidence from International Stock Markets". Journal of Banking and Finance, 21, pp. 143-167.

COCHRANE, J.H. (2011). "Discount Rates". Journal of Finance, 66, pp. 1047-1108.

CURTRIGHT, T.L. and ZACHOS, C.K. (2015). "Elementary Results for the Fundamental Representation of SU(3)". Reports on Mathematical Physics 76, pp. 401-404.

DANIEL, K.D. and TITMAN, S. (1997). "Evidence on the Characteristics of Cross-Sectional Variatino in Stock Returns". Journal of Finance, 52, pp. 1-33.

ELIOT, T.S. (1971). "The Dry Salvages". Four Quartets, pp. 35-46. New York: Harcourt Brace Jovanovich; New York: Harcourt, Brace and Company (1st ed. 1970).

ERDMANN, K. and WILSON, M. (2000). Introduction to Lie Algebras. London: Springer.

ESTRADA, J. (2002). "Systematic Risk in Emerging Markets: The D-CAPM". Emerging Markets Review, 3, pp. 365-377.

ESTRADA, J. (2007). "Mean-Semivariance Behavior: Downside Risk and Capital Asset Pricing". International Review of Economics and Finance, 16, pp. 169-185.

EZHELA, V.V. et al. (eds.) (1996). Particle Physics: One Hundred Years of Discoveries. Woodbury. N.Y.: American Institute of Physics.

FAMA, E.F. (1991). "Efficient Capital Markets: II". Journal of Finance, 46, pp. 1575-1617.

FAMA, E.F. and FRENCH, K.R. (1992). "The Cross-Section of Expected Stock Returns". Journal of Finance, 47, pp. 427-465.

FAMA, E.F. and FRENCH, K.R. (1995). "Size and Book-to-Market Factors in Earnings and Returns". Journal of Finance, 50, pp. 131-155.

FAMA, E.F. and FRENCH, K.R. (1996). "Multifactor Explanation of Asset Pricing Anomalies". Journal of Finance, 51, pp. 55-85.

FAMA, E.F. and FRENCH, K.R. (2004). "The Capital Asset Pricing Model: Theory and Evidence". Journal of Economic Perspectives, 18(3), pp. 25-46.

FAMA, E.F. and FRENCH, K.R. (2008). "Dissecting Anomalies". Journal of Finance, 63, pp. 1653-1678.

FAMA, E.F. and FRENCH, K.R. (2012). "Size, Value, and Momentum in International Stock Returns". Journal of Financial Economics, 105, pp. 457-472.

FICHTE, J.G. (1993a). "A Comparison Between Prof. Schmid's System and the Wissenschaftslehre." In D. Breazeale (trans.): Fichte: Early Philosophical Writings (pp. 243-306). Ithaca, N.Y.: Cornell University Press.

FICHTE, J.G. (1993b). "Review of Aenesidemus". In D. Breazeale (trans.): Fichte: Early Philosophical Writings (pp. 58-77). Ithaca, N.Y.: Cornell University Press.

FLANNERY, M.J. and PROTOPAPADAKIS, A.A. (2002). "Macroeconomic Factors Do Influence Aggregate Stock Returns". Review of Financial Studies, 15, pp. 751-782.

GELL-MANN, M. (1964). "A Schematic Model of Baryons and Mesons". Physics Letters, 8, pp. 214-215.

GELL-MANN, M. (1994). The Quark and the Jaguar: Adventures in the Simple and the Complex. New York: W.H. Freeman.

GRAY, J.B. and FRENCH, D.W. (1990). "Empirical Comparisons of Distributional Models for Stock Index Returns". Journal of Business Finance and Accounting, 17, pp. 451459. 
GRIFFIN, J.M. (2002). "Are the Fama and French Factors Global or Country Specific?". Review of Financial Studies, 15, pp. 783-803.

GRINBLATT, M.; TITMAN, S. and WERMERS, R. (1995). "Momentum Investment Strategies, Portfolio Performance, and Herding: A Study of Mutual Fund Behavior". American Economic Review, 85, pp. 1088-1105.

HALL, B.C. (2015). Lie Groups, Lie Algebras, and Representations: An Elementary Introduction (2nd ed.). Cham, Switzerland: Springer International Publishing.

HARARI $H$. and STANFORD LINEAR ACCELERATOR CENTER (1997). "Three Generations of Quarks and Leptons". In Proceedings of the XII Rencontre de Moriond, pp. 170-184. Gif sur Yvette, France: Editions Frontières.

HELGASON, S. (1978). Differential Geometry, Lie Groups, and Symmetric Spaces. New York: Academic Press.

ICKE, V. (1995). The Force of Symmetry. Cambridge: Cambridge University Press.

JAGANNATHAN, R. and WANG, Z. (1996). "The Conditional CAPM and the Cross-Section of Expected Returns". Journal of Finance, 51, pp. 3-53.

JAWORSKI, P.; DURANTE, F.; HÄRDLE, W.K. and RYCHLIK T. (eds.) (2010). Copula Theory and Its Applications. Heidelberg: Springer.

JEGADEESH, N. and TITMAN, S. (1993). "Returns to Buying Winners and Selling Losers: Implications for Market Efficiency". Journal of Finance, 48, pp. 65-91.

KAHNEMAN, D. and TVERSKY, A. (1979). "Prospect Theory: An Analysis of Decision Under Risk". Econometrica, 47, pp. 263-291.

KAPLINSKI, G. (2004). "Traditional Beta, Downside Risk Beta and Market Risk Premiums". Quarterly Review of Economics and Finance, 44, pp. 636-653.

KOLLER, T.; GOEDHART, M. and WESSELS, D. (2010). Valuation: Measuring and Managing the Value of Companies (5th ed.). Hoboken, N.J.: Wiley.

KON, S.J. (1984). "Models of Stock Returns - A Comparison". Journal of Finance, 39, pp. 147-165.

KORAJCZYK, R.A. (1999). "Introduction." In R.A. Korajczyk (ed.), Asset Pricing and Portfolio Performance: Models, Strategy and Performance Metrics. London: Risk Books.

KUHN, T.S. (1970). The Structure of Scientific Revolutions (2nd ed.). Chicago: University of Chicago Press.

LEIBOWITZ, M.L.; BOVA, A. and HAMMOND, P.B. (2010). The Endowment Model of Investing: Return, Risk, and Diversification. Hoboken, N.J.: John Wiley \& Sons.

LEVY, H. (2009). "The CAPM Is Alive and Well: A Review and Synthesis". European Financial Management, 16, pp. 43-71.

LEVY, H. (2012). The Capital Asset Pricing Model in the 21st Century: Analytical, Empirical, and Behavioral Perspectives. New York: Cambridge University Press.

LIEW, J. \& VASSALOU, M. (2000). "Can Book-to-Market, Size and Momentum Be Risk Factors That Predict Economic Growth?" Journal of Financial Economics, 57, pp. 221245.

LIU, D.X. (2000). "On Default Correlation: A Copula Function Approach". Journal of Fixed Income, 9(4), pp. 43-54.

LOPES, L.L. (1987). "Between Hope and Fear: The Psychology of Risk". Advances in Experimental Social Psychology, 20, pp. 255-295. 
LOUGHRAN, T. and RITTER, J.R. (2000). "Uniformly Least Powerful Tests of Market Efficiency". Journal of Financial Economics, 55, pp. 361-390.

MANDELBROT, B.B. and HUDSON, R.L. (2004). The (Mis)Behavior of Markets: A Fractal View of Risk, Ruin, and Reward. New York: Basic Books.

MANN, R. (2010). An Introduction to Particle Physics and the Standard Model. Boca Raton, Fla.: CRC Press.

MANTEGNA, R.N. and STANLEY, H.E. (2000). An introduction to Econophysics: Correlations and Complexity in Finance. Cambridge: Cambridge University Press.

MARKOWITZ H.M. and USMEN, N. (1996). "The Likelihood of Various Stock Market Return Distributions, Part 2: Empirical Results". Journal of Risk and Uncertainty, 13, pp. 221-247.

McQUEEN, G. and ROLEY, V.V. (1993). "Stock Prices, News, and Business Conditions". Review of Financial Studies, 6, pp. 683-707.

MEHRA, R. (2003). "The Equity Premium: Why Is It a Puzzle?". Financial Analysis Journal, 59(1), pp. 54-69.

MEHRA, R. and PRESCOTT, E.C. (2003). "The Equity Premium Puzzle in Retrospect". In G.M. Constantinides, M. Harris and R.M. Stulz (eds.): Handbook of the Economics of Finance, pp. 889-938. Amsterdam: Elsevier/North Holland.

MERTON, R.C. (1974). "On the Pricing of Corporate Debt: The Risk Structure of Interest Rates". Journal of Finance, 29, pp. 449-470.

MERTON, R.C. (1980). "On Estimating the Expected Return on the Market: An Exploratory Investigation". Journal of Financial Economics, 8, pp. 323-361.

MERTON, R.C. (1987). "A Simple Model of Capital Market Equilibrium with Incomplete Information". Journal of Finance, 42, pp. 483-510.

MILLER, M.B. (2014). Mathematics and Statistics for Financial Risk Management (2nd ed.). Hoboken, N.J.: John Wiley \& Sons.

MILLS, T.C. (1995). "Modelling Skewness and Kurtosis in the London Stock Exchange FT-SE Index Return Distributions". Statistician, 44, pp. 323-332.

MINA, J. and XIAO, J.Y. (2001). Return to RiskMetrics: The Evolution of a Standard. New York: RiskMetrics Group.

MORELLI, D. (2007). "Beta, Size, Book-to-Market Equity and Returns: A Study Based on UK Data". Journal of Multinational Financial Management, 17, pp. 257-272.

MUNOWITZ, M. (2005). Knowing the Nature of Physical Law. Oxford: Oxford University Press.

NELSON, R.B. (1999). An Introduction to Copulas. New York: Springer.

OERTER, R. (2006). The Theory of Almost Everything: The Standard Model, the Unsung Triumph of Modern Physics. New York: Pi.

PANTALEO, P.V. and RIDINGS, B.W. (1996). "Reorganization Value". Business Lawyer, 51, pp. 419-442.

PETTENGILL, G.N.; SUNDARAM, S. and MATHUR, I. (1995). "The Conditional Relation Between Beta and Returns". Journal of Financial and Quantitative Analysis 30, pp. 101116.

PEIRÓ, A. (1999). "Skewness in Financial Returns". Journal of Banking and Finance 23, pp. 847-862.

PINSKY, R. (1994). The Inferno of Dante. New York: Farrar, Straus \& Giroux. 
POLCHINSKI, J. and STRASSLER, M.J. (2002). "Hard Scattering and Gauge/String Duality". Physics Review Letters, 88, pp. 31601.

PRATT, S.P. and GRABOWSKI, R.J. (2010). Cost of Capital: Applications and Examples (4th ed.). Hoboken, N.J.: John Wiley \& Sons.

PREIS, T. and STANLEY, H.E. (2010). "Switching Phenomena in a System with No Switches". Journal of Statistical Physics, 138, pp. 431-446.

RATH, S. and DURAND, R.B. (2015). "Decomposing The Size, Value And Momentum Premia of The Fama-French-Carhart Four-Factor Model". Economics Letters, 132, pp. 139-141.

REINGANUM, M.R. (1981). "Misspecification of Capital Asset Pricing: Empirical Anomalies Based on Earnings' Yield and Market Values". Journal of Financial Economics, 9, pp. 19-46.

RICHMOND, P.; MIMKES, J. and HUTZLER, S. (2013). Econophysics and Physical Economics. Oxford: Oxford University Press.

ROEHNER, B.M. (2005). Patterns of Speculation: A Study in Observational Econophysics. Cambridge: Cambridge University Press.

ROSEN, S.P. (1971). "Finite Transformation in Various Representations of SU(3)". Journal of Mathematical Physics, 12, pp. 673-681.

SAVOR, P. and WILSON, M. (2016). "Earnings Announcements and Systematic Risk". Journal of Finance, 71, pp. 83-138.

SCHWARTZ, C. (1997). A Tour of the Subatomic Zoo: A Guide to Particle Physics. San Rafael, Cal.: Morgan \& Claypool Publishers.

SHEFRIN, H. and STATMAN, M. (2000). "Behavioral Portfolio Theory". Journal of Financial and Quantitative Analysis, 35, pp. 127-151.

SITABHRA, S.; CHATTERJEE, A.; CHAKRABORTI, A. and CHAKRABARTI, B.K. (2011). Econophysics: An Introduction. Weinheim, Germany: Wiley-VCH.

TALEB, N.N. (2007). The Black Swan: The Impact of the Highly Improbable. New York: Random House.

TSAI, H-J.; CHEN, M-C. and YANG, C-Y. (2014). "A Time-Varying Perspective on the CAPM and Downside Betas" International Review of Economics and Finance, 29, pp. 440-454.

TVERSKY, A. and KAHNEMAN, D. (1992). "Advances in Prospect Theory: Cumulative Representation of Uncertainty". Journal of Risk and Uncertainty, 5, pp. 297-323.

WATSON, J.D. (2001). The Double Helix: A Personal Account of the Discovery of the Structure of DNA. New York: Touchstone Books; New York: New American Library (1st ed. 1968).

WIENER, R.M. (2010). "The Mysteries of Fermions". International Journal of Theoretical Physics, 49, pp. 1174-1180.

WILSON, K.G. (1974). "Confinement of Quarks". Physics Review D, 10, pp. 2445-2459.

XU, P. and PETTIT, R. (2014). "No-Arbitrage Conditions and Expected Returns When Assets Have Different $\beta$ 's in Up and Down Markets". Journal of Asset Management, 15, pp. 62-71.

ZHANG, L. (2005). "The Value Premium”. Journal of Finance, 60, pp. 67-103.

ZWEIG, G. (1980). "An SU(3) Model for Strong Interaction Symmetry and Its Breaking". In D.B. Lichtenberg and S.P. Rosen (eds.): Developments in the Quark Theory of Hadrons (vol. 1), (pp. 22-101). Nonantum, Mass.: Hadronic Press. 